\title{
The cultural aspect in the contextualisation of pastoral caregiving ministry
}

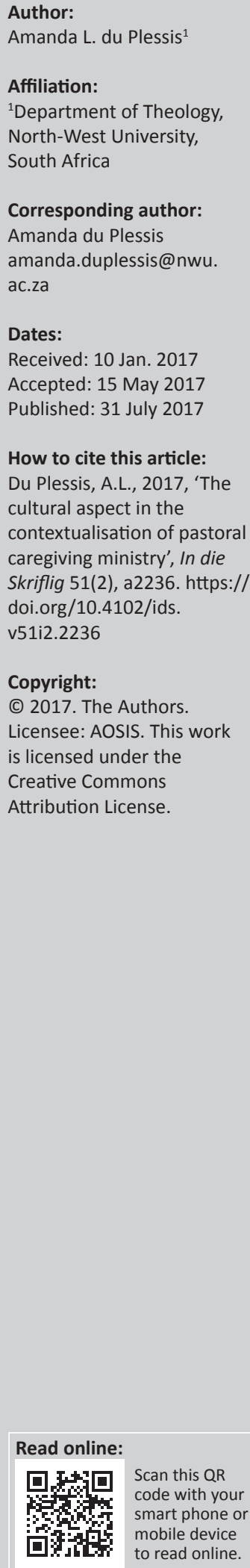

Due to the political changes during the last three decades in South Africa, many voices raised for the post-colonializing of sciences. This is also applicable to the pastoral caregiving ministry. Although the science of pastoral caregiving in South Africa has developed into an authentic recognised science, it seems as if the development followed in the fashion of the Western context and the call for the contextualising of pastoral caregiving for all the people of South Africa was mostly ignored. It was only at the end of the 20th century that the concept of interculturality emerged to indicate that such an approach could be more appropriate that an incultural approach. Since then many scholars wrestles with the aspect of culture in the contextualising of pastoral care and the challenge of staying true to the Word of God. In this regard, the research question concentrates on the interwovenness between the Christian faith and the different cultures of the people of South Africa: How can pastoral caregiving be contextualised in the different cultures of South Africa while staying true to God's gospel. The central theoretical argument is that the contextualising of pastoral care rest on hermeneutical principles that form a bridge between the Bible text and its application in the circumstances and needs of the people of South Africa. The article unfolds by looking at the compatibility and/or incompatibility of Western and African cultures, the effect of monocultural ethnocentric bias, and concludes with the principles of a Christian culture and its implications for the pastoral caregiving process of addressing certain challenges in people's experiences of life.

\section{Introduction}

In his book, Post-colonializing God, Lartey (2013) pleads for a paradigm shift away from globalisation to the internationalisation and ultimately indigenisation of Practical Theology in South Africa. ${ }^{1}$ He positions indigenisation as a counterbalance to the Western biases inherent in the pastoral caregiving process. It advocates for indigenous African practitioners of the African traditional art of spiritual care and reflective healing practices in a post-colonializing era. In this view, pastoral caregiving is seen as a double-edged sword, with the twofold goal of community building and community transformation. The handle of the sword is the incorporation of spirituality as an umbrella term that includes divinity, psychology, social and ecological dimensions. Although Lartey's discussion seems to be a workable solution, the question can be asked if his model for indigenisation of pastoral care is, in effect, not just the other end of a continuum opposed to the Western culture on the one end. The emeritus archbishop Desmond Tutu (1994:2) used the term rainbow nation to describe the different cultures we are dealing with in South Africa. My understanding of this metaphor is that, just as the different colours of a rainbow are alongside each other, the people of South Africa must live in peace and harmony alongside each other, despite the cultural differences. However, the instability of the political climate of the day and the resulting socio-economic problems rather divide the people of South Africa than to inspire them to work towards a suitable solution in making the dream of a rainbow nation a reality. The incompatibility of the different cultures, worldviews and even religions seems to be at the root of many evils that manifest as misunderstandings, conflict, racism, sexism, xenophobia, et cetera (Du Plessis 2016:1). These clashes have an impact on social, economic and political spheres and inhibit future growth. It seems as if the people of South Africa must halt and rethink the way towards an understanding of each other's cultures and worldviews. In my view, this can only be done with proper cultural education when we start to speak about the differences with an openness and tolerance. There must also be acknowledgment and forgiveness for the sufferings

1.While Lartey (2013) pleads for the indigenisation of pastoral care in his book Post-colonializing God, he once advocated the interculturality of pastoral care. In 1997 he wrote the book In living colour. An intercultural approach to pastoral care and counseling, which was published by Cassell in London. A gradual paradigm shift is therefore evident in Lartey's work when one looks at the definitions of the terminology he uses. He (Lartey 2013:118) defines globalisation as a comprehensive pastoral ministry based on Western research and methodology, and internationalisation as an effort to work interculturally or cross-culturally. However, he states that the huge gap between the Western and African methodology only adds to the deficiency of internationalisation. He criticises an intercultural approach as at its best, exotic, and at its worst, unprofessional. Indigenisation is seen as the counterbalance for Western predispositions. 
of the past, and a commitment to growth and nation building with a non-judgemental attitude. It seems as if the people of South Africa have to start on a clean slate ${ }^{2}$ where neither the past nor the future is romanticised; the differences and the needs are acknowledged and named; action is taken against social and humanitarian evil, and social justice is advocated with a prophetic discernment. The following question remains: How will this be possible? Is a discourse of postcolonializing in effect not the same as a discourse about colonializing? They are the two ends of a continuum. The post-colonializing of God in effect equals the colonializing of God. It is to put the transcendent God - who is both outside and inside time and space - in a certain culture instead of putting a culture in God to be transformed according to the Gospel. ${ }^{3}$ Over the centuries, God have always worked through a certain culture to reach the different nations. The challenge for the pastoral caregiving ministry of the church is therefore to play an active role in the transition of the people of South Africa with pastoral caregiving based on sound exegeses of Scripture where the Gospel and culture are not placed against each other. Furthermore, although we cannot deny the different cultures, we can work towards confirming the good in the different cultures with true understanding. The outcome can be a culture where the covenant relationship with Yahweh can find expression in moral action and upright living. True pastoral caregiving is based on the word of God as the source of the truth through the guidance of the Holy Spirit and it must be done with an attitude of unconditional love, forgiveness and acceptance so that the people of South Africa can enter a new life, unity and wholeness in Christ (Mwiti \& Dueck 2006:70).

This article wants to contribute to the contextualisation process of pastoral caregiving in South Africa and forms a small part of the discourse of the transformation of Practical Theology in South Africa. It therefore follows from a pastoral caregiving epistemology and investigates the pastoral caregiver's responsibility to provide guidance in the contextualisation of pastoral caregiving to the people of South Africa within an intercultural paradigm to avoid the mistakes of the past. I acknowledge that pastoral caregiving has overlapping areas with other scientific research fields such as psychology, sociology and anthropology, especially when it comes to rethinking a theme such as the theme of this article. The primary difference between pastoral caregiving and the overlapping sciences is that the latter is mainly based on clinical facts, principles and theories, whereas pastoral caregiving is a theological science about God's encounter with people based on the covenantal relationship between God and human beings. In this sense, Louw (2010a:73) postulates that the basis of pastoral caregiving is 'the expression and representation of the sensitivity and compassion of the Scriptures' understanding and portrayal of God's encounter, intervention, interaction and involvement in our human being'. For the believer, the meaning of life lies

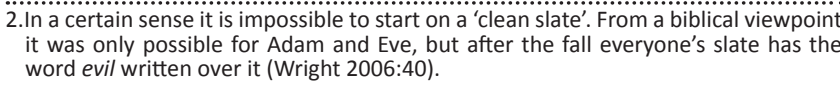

3.A more detailed discussion of Christ and culture follows later in the article. in the truth of God and his actions through history. Proper acceptable actions result from being a true follower of Christ, and self-acceptance as a fundamental prerequisite for the acceptance of others is based on the acceptance of God's unconditional love for humans. In this regard, the research question concentrates on the interwovenness between the Christian faith and the different cultures of the people of South Africa: How can pastoral caregiving be contextualised in the different cultures of South Africa while staying true to the gospel of God. The central theoretical argument is that the contextualising of pastoral care rest on hermeneutical principles that form a bridge between the Bible text and its application in the circumstances and needs of the people of South Africa. The article unfolds by looking at the compatibility and/or incompatibility of Western and African cultures, the effect of monocultural ethnocentric bias, and concludes with the principles of a Christian culture and its implications for the pastoral caregiving process of addressing certain challenges in people's experiences of life.

\section{The compatibility and/or incompatibility of Western and African cultures}

According to Mwiti and Dueck (2006:34), culture is the incorporation of the traditions and customs of a given group of people. It is therefore the worldview that determines who they are as human beings and how they perceive their humanity. Another dimension of culture is also seen in how they relate to other people who do not belong to their group and how they pass on their customs as a legacy to future generations within their own group. ${ }^{4}$ Van der Walt (2007:44) uses the metaphor of a tree to describe the interdependent relationship between culture, worldview and religion. In this metaphor, religion is seen as the roots, worldview as the trunk and culture as the branches of the tree. People's behaviour is seen as the fruits of the tree. To make a distinction between the three concepts, religion is the central directedness of all human life towards the real God or presumed gods; a worldview is the human being's perspective on created reality; and culture is life in its totality (Van der Walt 2007:46). Every culture has its good and bad, and not one culture is more acceptable than another (Louw 2008:151). In the narrowest sense, human beings are in four relations, namely in relation to God, in relation to other human beings, in relation to themselves and in relation to nature. One of these relationships is considered dominant and is therefore the determining factor for the other three relations.

Every culture has the potential to change and while certain deeds or acts can be changed by learning new behaviour, real change in a culture is only possible when the deepest layer (namely religion) is changed. This statement is important to our discourse, because in South Africa there are four possible reactions to the need of real change in a culture that can

4.Mwiti and Dueck $(2006: 20)$ also state their concern about the barriers to documenting African knowledge due to the oral tradition in which wisdoms and documenting African knowledge due to the oral tradition in which wisdoms and
customs have been passed from generation to generation without proper written documentation. 
contribute to the contextualisation (or transformation) of the pastoral caregiving ministry ${ }^{5}$ (Van der Walt 2007:56). First, there is a certain viewpoint that transformation is only possible through the revival of traditional African culture (Africanisation). The second viewpoint is that the African culture is inferior and has to be changed completely to the Western culture (westernisation). The third viewpoint is a plead for an eclectic mixture of the Western and African cultures without in-depth change to either one (multiculturalism). The last viewpoint is a plead for careful accommodation (acculturation) of beneficial aspects of the different cultures (inculturation and interculturation). Berry (1997:30) further suggests four possible outcomes of the acculturation process: assimilation (movement toward the dominant culture), integration (synthesis of cultures), rejection (reaffirmation of the traditional culture) or marginalisation (alienation from both cultures). When we consider the escalating number of challenges that the people of South Africa are still facing more than two decades after democracy, is it possible that our rainbow nation dream ended on the rock due to globalisation? Globalisation promotes and even forces the integration of different cultures and leads to an interdependency and vulnerability that result in the erection of new barriers. A lack of clear cultural identity results in poor self-respect and self-esteem, little confidence in one's own ability, and therefore a passivity that does not add to nation building and transformation.

As mentioned earlier, a worldview is someone's perspective on creating reality and is therefore important to the theme. Five basic Christian worldviews, as summarised in Table 1, have become evident throughout the centuries:

As seen in the table of the typology of the five basic Christian worldviews, the first four are dualistic viewpoints. The problem lies in the dualistic nature instead of a holistic ${ }^{6}$ nature. Van der Walt (2003) explains this as follows:

TABLE 1: Five basic Christian worldviews.

\begin{tabular}{lll}
\hline Niebuhr (1952) & Olthuis, Hart and Seerveld (1970) & Wolters (1990) \\
\hline Christ against culture & $\begin{array}{l}\text { Right bank extreme (Tertullian, } \\
\text { Anabaptism, older evangelism, } \\
\text { dialectical theology, e.g. Barth) }\end{array}$ & $\begin{array}{l}\text { Grace opposes } \\
\text { nature }\end{array}$ \\
Christ of culture & $\begin{array}{l}\text { Left bank extreme (from Origen } \\
\text { and Justine, to modern } \\
\text { theologians like Ritschl, Tillich } \\
\text { and the social gospel movement) }\end{array}$ & $\begin{array}{l}\text { Grace equals } \\
\text { nature }\end{array}$ \\
Christ above nature & $\begin{array}{l}\text { Moderate, middle of the stream } \\
\text { type-to the left (Thomism, } \\
\text { Neo-Thomism, Catholicism) }\end{array}$ & $\begin{array}{l}\text { Grace perfects } \\
\text { nature }\end{array}$ \\
Christ and culture in & $\begin{array}{l}\text { Moderate, middle of the stream } \\
\text { type- more to the right } \\
\text { (Lutheranism) }\end{array}$ & $\begin{array}{l}\text { Grace stands } \\
\text { alongside nature }\end{array}$ \\
Christ transforms nature & $\begin{array}{l}\text { Reformational-biblical model } \\
\text { (Augustine, Calvin, Kuyper, } \\
\text { Bavinck, Olthuis, Wolters - } \\
\text { Niebuhr's own position is not } \\
\text { clear) }\end{array}$ & $\begin{array}{l}\text { Grace restores } \\
\text { nature }\end{array}$ \\
\hline
\end{tabular}

Source: Van der Walt 2003:527.

5.The different scholars who write each viewpoint are mentioned later in the article.

6.According to a holistic viewpoint (Niebuhr 1952: Christ transforms nature; Olthuis, Hart \& Seerveld 1970: reformational-biblical model; and Wolters 1990: grace Hart \& Seerveld 1970: reformational-biblical model; and Wolters 1990: grace
restores nature), Christ is the transformer of culture. He operates through it to transform or convert it. This is discussed later on in the article.
The basic mistake ... can also be explained by saying that Christians ascribed an ontological (or structural) character to the religious (or directional) antithesis between obedience and disobedience to God: one part of creation (the sacred) was regarded to be good by nature, while the other was considered to be of less importance or even evil by nature. (p. 515)

This resulted in a double-mindedness, for example certain activities in life (like going to church) are holy, while others (like going to the mall) are not. In this view, Christianity is therefore something a Christian does at given periods ${ }^{7}$ and not who they really are. Christianity is not reflected in their identity or their view of being human. Culture and religion are then seen as two dimensions that can be separated instead of two inseparable dimensions. The result is the accommodation of a different culture in someone's religious dimension that ends in monocultural ethnocentric biases. This is the theme of discussion in the next part of the article.

\section{The effect of monocultural ethnocentric bias}

Monocultural ethnocentric bias is 'a status that robs people of their culture, impoverishes their collective unconscious, negatively impacts their identity, and compromises their coping ability's (Sue \& Sue, 1999:35). The effect of monocultural ethnocentric bias is that colonialism forced Africans to disregard their uniqueness, making them ashamed of their dances, poetry, music and even their thought systems (Mwiti \& Dueck, 2006:23). Schutte (2004) refers to monocultural ethnocentric bias as the deepest manifestation of sin and describe it as:

$[A] n$ inner slavery, an inability to exercise one's capacity of freedom. The wound is so deep that our freedom is destroyed. And just as only, a transcendent power can create beings like us with the capacity for self-determination, so only a transcendent power can enable that capacity to develop or revive when it has been destroyed. (p. 47-57)

In a similar vein, Kretzschmar (1986:63) quote Steve Biko's words that the most potent weapon in the hands of an oppressor is the mind of the oppressed and adds, '[T]he black man is enslaved by his own thinking and attitudes more effectively than by his enslavements to any power outside himself.' The black consciousness movement calls for a discovery and affirmation of their identity. If this is misunderstood, much of the more emotive language will be even more misunderstood. The quest for African identity is a focal point of the very complex process of cultural reinterpretation. It seems that the strongest rationale behind this wish to recover African identity is the urge to rid the African people of its negative self-image and mind-set of dependency due to the exposure and mixture of cultures. In

\footnotetext{
7.Tutu (1994:204) states that religion does not deal with a certain compartment of life, but because all life belongs to God, all life - and therefore, all of creation - is life, but because all life belongs to God, all life - and therefore, all of creation - is religious. To understand this concept that life is religion, Van der Walt's (2003:539) explanation is included, namely that religion is not something in addition to life, but its essence; it is not a complement to existence, but its character; it is not higher than "ordinary" life, but its central thrust ... Religion or spirituality is a way of life that people engage in with their full existence at all times.
}

8.Mwiti and Dueck (2006:37) refer to this as 'anthropological impoverishment'. 
an attempt to avoid blame shifting based on the different cultural ends of the continuum, Byang (1975:182) pleaded that the 'new African church' (sic) community must continue to 'express Christianity in a truly African context, allowing the faith to judge the African culture and never allowing the culture to take precedence over Christianity'. A quest for the contextualising of pastoral caregiving ministry in South Africa is therefore not a discourse about African or Western, but a discourse on biblical hermeneutical views that are relevant to the needs of all the different cultures in South Africa in their unique context.

Although Christianity is not a culture or worldview, but an intersubjective covenantal relationship between God and human beings, the Christian faith always takes in a specific cultural context or worldview. Du Toit (1998:373) states that the church (or pastoral caregiver) must expand their understanding of hermeneutics to include a holistic look at religion, religious understanding, interpretation and communication, because perceptions of God, religious experience, self-esteem, worldview and the like are all vitally determined by one's basic living conditions. The best way to understand people is to find out where their needs are met. Therefore, he describes the interpretation of the Bible as if it moves in a circle until the interpreter is convinced of a satisfactory interpretation - the process is never-ending. Hermeneutics can help us to understand why people differ. Du Toit (1998) highlights that:

at the end of the day the search for African identity is not wholesale acceptance of either an African or a European oriented culture, it is an acceptance of what is good, presumably for the dignity and well-being of homo Africans. (p. 389)

This is directly linked to the covenantal relationship between God and human beings.

Although the science of pastoral caregiving in South Africa has developed into an authentic recognised science, it seems as if the development followed in the fashion of the Western context and the call for the contextualising of pastoral caregiving for all the people of South Africa was mostly ignored. It was only at the end of the 20th century that the concept of interculturality emerged to indicate that such an approach could be more appropriate that an incultural approach ${ }^{9}$ (Louw 2010b:181). A further impediment of the contextualising process is the conflicting opinions on the foundation for African theology. Although it is a generalisation, Du Toit (1998:395) roughly distinguishes between two groups. He describes the first group as the so-called old-guard theologians. This group includes theologians such as E.W. Fashole-Luke, Bolji Idowu, John Mbiti, Itumeleng Mosala and Harry Sawyer, who seem to have taken the Western Christian theology, develop it in African terms, and call it 'indigenisation'. In this approach, the African traditional values and experiences have become a passive partner, subordinate to the presumably superior Western theology.

9. Louw (2010b:181) explains that there is not much difference between inculturality and interculturality. The first emphasises interpenetration, while the second emphasises exchange. Inculturality is an attempt to create a spirituality that is emphasises exchange. Inculturality is
rooted in the basic experiences of life.
The second group is the new-guard theologians. It includes theologians such as Eboussi Boulaga, Jean-Marc Ela, Ambrose Moyo, Kwame Bediako and Mercy Oduyoye. In the 1980s they rejected the indigenization process, affirming African traditional values and avoiding 'Western bourgeois' values. They called on scholars to use the hermeneutical perspectives of liberation when interpreting the Bible.

The latter concludes with the explanation given by Kaiser and Silva (2007:35-46) and Duvall and Hays (2012:234-247) for the application of the Bible text for the reader or hearer of today. They conclude that the exegetical process is only really completed when the exegete indicates what the text (passage) says to the present-day hearers or readers, and that the message of the past (what the text meant) is transferred as a message for today (what the text means), with due consideration of the difference in circumstances between the past and today. In the explanation and interpretation of the text, the contemporary readers or listeners can recognise the relevance in their life circumstances. Considering this, it seems as if the contextualising of pastoral caregiving ministry in South Africa is not determined by the indigenisation thereof. It rather depends on hermeneutical principles that form a bridge between the Bible text and its application in the circumstances and needs of the people of South Africa.

This leaves us with the questions of what it means to be Christian within a culture. Christian culture is neither African, nor Western or even Eastern, but at the same time, embedded in all cultures (Mwiti \& Dueck 2006:37). Being Christian within a certain culture is to be shaped by Jesus Christ's message of the reign of God. It transcends colour, race and gender, and at the end celebrates cultural heritage. Bediako (2004:1) writes that Christianity is 'one song sung by many tongues'. Even in the book of Revelations there is a reference to the different tribes, languages and nations of the earth. Pastoral caregivers therefore live with the imperative to be students of the culture they work in. The role of pastoral caregiving in South Africa is in effect then to re-member those who were dis-membered based on differences. Villa-Vicencio (1994:120) connects interculturality to the necessity of an interreligious dialogue and states that, "with the forging of a common sense of belonging' the people of South Africa must exercise cultural openness with a presumption of equal worth. Interculturality is in fact a creative response to the diversity, differences and pluralism that is evident in today's society and the postmodern culture of globalisation (Louw 2010b:182). Lartey (1997:11) wrote that an intercultural approach to pastoral care calls for the affirmation of three basic principles, namely contextuality (the framework of surrounding beliefs and worldviews), multiple perspectives (listening to and dialogue within different perspectives) and authentic participation (the mutual concern for the integrity of the other). In my view, this is a much more balanced discourse, as it is the middle ground on the continuum mentioned previously in the article.

Louw (2010b:182) summarises the essence of interculturality as he states 'interculturality in pastoral care is less about the 
technique (counselling and communication skills) and more about the quality of the interaction and encounter (being with skills)'. This also relates to the definition of the essence of pastoral care as the love commandment, which must find expression in the relational dimension between God and human beings and between fellow human beings. Mwiti and Dueck (2006:38) voice that the Christian in culture ought to be rich in individual and communal expressions of faith that are connected upwards to God, inwards to the transformation of individuals and outwards, touching others and impacting the world. Healing and wholeness do not come from selfcenteredness, but from a centeredness on God and others. Pastoral caregiving, in an intercultural care context, will focus less on psychoanalysis and more on socio-cultural issues (Louw 2010b:183). This statement links to what Lartey (2013:119) called the double edge of the sword' as a metaphor for community building and transforming. In this way a holistic understanding of human experience in the different cultures is developed. Louw (2010b) raises an important aspect regarding an intercultural approach and explains its transspection dimension as

an effort to put oneself into the head (not shoes) of another person ... a trans epistemological process which tries to experience a foreign belief, a foreign assumption, a foreign perspective and feelings in a foreign context. (p. 184)

In practice this means that in a trans-epistemological process of experiencing the different cultures, the people of South Africa must become brutally honest about whether their culture serves the supreme God or not and if their traditional religious and cultural views are not just sprinkled with holy water to make them more acceptable. The next section of the article discusses the principles of a biblical-reformational worldview and its implications for the pastoral caregiving process of addressing certain challenges in people's experiences of life.

\section{Principles of a biblical-reformational worldview}

Van der Walt (2003:102) indicates very strongly that the biblical message is clear: 'The Gospel associated itself with different cultures - never to be domesticated, nor to be the captive of these cultures, but to liberate and transform them.' When taking the illustration of the continuum presented in the introduction part of this article into consideration, it is clear that the contextualisation of pastoral caregiving ministry in South Africa will not be found in the revival of one particular culture, be it African or Western culture. Although diversity is at the core of an intercultural approach, humanity has much in common. Every human being has basic human needs, for instance physical and survival needs, the need for security and safety, the need to belong to a family and a community, the need to love and be loved, respected and accepted, and a need for recognition as a fellow human being. Therefore, the transformation boils down to the reformation of pastoral care so that it stays true to a biblically inspired worldview, based on the concepts of creation (formation), the fall (deformation) and redemption (reformation) (Van der Walt 2007:77). At the time of the creation, the direction of life was towards God and human beings were created in the image of God (imago Dei). After the fall, the direction of life was away from God and human beings wanted to be like God (sicut Dei). Currently, Christians are living between the time of redemption and consummation. The church has the commission of missio Dei and Coram Dei that links to the twofold will of God as mentioned in 1 Timothy 2:3-4. Paul had to preach to the Gentiles (intercultural), and those who are saved must come to the knowledge of truth (Church 1961:1888). Without the knowledge of the truth of salvation, the human heart cannot be good. Given these facts, the objectives of pastoral caregiving is to re-establish the connection between God and human beings and between fellow human beings. In a sense, it is to restore creation and to seek wholeness in the recognition of the brokenness and the facilitation of reconciliation.

The goal of pastoral caregiving is change, and ways to bring about change are culturally dependent. According to Crear (2011:502), a major assumption for culturally effective pastoral caregiving is that we can 'acknowledge our own basic tendencies, the way we comprehend other cultures, and the limits our culture places on the comprehension'. This statement correlates with the essential dimensions that Sue, Arredondo and McDavis (1992:477) identified for intercultural pastoral caregiving. Two other dimensions are the understanding of the different worldviews, and that pastoral caregivers must intentionally learn and practice relevant interventions, strategies and techniques for working in an intercultural way.

Van der Walt's understanding (2007:62) of a biblically inspired worldview is that Christians believe that they must serve God (directional) according to his view (normative) in his creation (structural). Louw (2000:25) describes it as staying true to the unique contribution to pastoral caregiving: 'the healing dimension of salvation'. Mwiti and Dueck (2006:70) describe it as an eclectic model that integrates indigenous cultural sensitivity, biblically grounded and a careful selection of nonAfrican biological, social and psychological insights. What seems to be important is that human beings ought to serve God in and with their culture; they cannot do it outside of their own culture. If they try to serve God in a foreign culture, it will not be relevant to their situation and results in dualism. This will lead to aspects of relative continuity and radical discontinuity (Van der Walt 2007:60). To understand this emphasis, we must again turn to the illustration of the continuum. An intercultural approach to pastoral caregiving means that there must be a certain movement towards the middle of the continuum. It allows for a relative continuity of the specific culture of birth and growth in the gospel and at the same time also a radical discontinuity where the gospel challenges and transforms the culture. Without this balanced contextualised movement or growth syncretism (Africanisation or westernisation of the gospel), dualism or an unhealthy accommodation will be the result.

Reformation or transformation means to deal with the evil in society and therefore also the acknowledgment of evil in culture. 
Evil is the force of anti-creation, anti-life - the force that opposes and seeks to deface and destroy. The theological premise of an intercultural approach is to restore the balance of power (Louw 2008:187). According to a biblical-reformed worldview, Christ has overcome the evil powers of darkness. Christian spirituality does not mean the balance of powers, but the transformation of power. Pastoral caregiving in an intercultural setting now has the twofold task of implementing the achievement of the cross of Jesus Christ and anticipating God's promised future world. The passing on of God's forgiveness is the most hopeful sign for community building and transformation (Wright 2006:103). Redemption is radical and works like salt to penetrate the old and to stop deterioration. This also means a return to the correct norms applicable to the different aspects of the lives of the people of South Africa, because without norms, no real transformation is possible. Louw (2008:187) also states that the point of departure should be Christology, with the emphasis on the incarnation. Incarnation is about the enfleshment of Christ and his identification with our predicaments. Incarnation and Christology are about the mediatory work of Christ - Christ died in our place and on our behalf. This is the basis of transformation in the core of every human being and culture can only change if the change manifests in the core.

\section{Conclusion}

The article unfolded by looking at the compatibility and/or incompatibility of Western and African culture and the effect of monocultural ethnocentric bias. It concluded with the principles of aChristian cultureand itsimplications for the contextualisation of the pastoral caregiving process of addressing certain challenges in people's experiences of life. Much more has to be said and written about the theme, but in my view, it is evident that the answer is not found in the revival of one particular culture, be it African or Western culture. A more balanced way has to be found by means of proper cultural education where we start to speak about the differences with an openness and tolerance. There must also be acknowledgment and forgiveness for the sufferings of the past and a commitment to growth and nation building with a non-judgemental attitude.

\section{Acknowledgements Competing interests}

The author declares that she has no financial or personal relationships which may have inappropriately influenced her in writing this article.

\section{References}

Bediako, K., 2004, Jesus and the Gospel in Africa: history and experience, Orbis Books, New York.

Berry, J.W., 1997, 'Immigration, acculturation and adaption', Applied Psychology 46(1), 5-34.

Byang, K.H., 1975, Theological pitfalls in Africa, Evangel Publishing House, Nairobi, Kenya.

Church, L.F., 1961, Matthew Henry's commentary, Zondervan, Grand Rapids, Michigan.

Crear, M.J., 2011, 'Assimilation and acculturation', in T. Clinton \& R. Hawkins (eds.), The popular encyclopaedia of Christian counselling, pp. 501-503, Harvest House Publishers, Eugene, Oregon.

Du Plessis, A.L., 2016, 'A Practical-theological reflection on the usage of symbols and metaphors in intercultural pastoral care in South Africa', HTS Teologiese Studies/ Theological Studies 72(2), a3517. https://doi.org/10.4102/hts.v72i2.3517

Du Toit, C., 1998, 'African hermeneutics', in S. Maimela \& A. König, A. (eds.), Initiation into theology: The rich variety of theology and hermeneutics, pp. 373-398, J.L. van into theology: The
Schaik, Pretoria.

Duvall, J.S. \& Hays, J.D., 2012, Grasping God's Word, Zondervan, Grand Rapids.

Kaiser, W.C. \& Silva, M., 2007, An introduction to biblical hermeneutics, Zondervan, Grand Rapids.

Kretzschmar, L., 1986, The voice of black theology in South Africa, Ravan Press, Johannesburg.

Lartey, E.Y., 1997, In living colour: An intercultural approach to pastoral care and counselling, Cassell, London.

Lartey, E.Y., 2013, Post-colonializing God: An African Practical Theology, SCM Press, London.

Louw, D.J., 2000, A hermeneutics of pastoral care and encounter, Lux Verbi BM, Cape Town.

Louw, D.J., 2008, Cura vitae: Illness and healing of life, Lux Verbi BM, Cape Town.

Louw, D.J., 2010a, 'Care of the human "soul" in contemporary theological formation: From "kerygmatics" to "fortigenetics" in pastoral anthropology", NGTT 51(3\&4), 70-81.

Louw, D.J., 2010b, "The hermeneutics of intercultural pastoral care: from "psyche" to "position" (habitus) within the healing dynamics of life (cura vitae)', Scriptura 103(1), 175-188.

Mwiti, G. \& Dueck, A.L., 2006, Christian counselling: An African indigenous perspective, Fuller Seminary Press, Pasadena, California.

Niebuhr, H.R., 1952, Christ and Culture, HarperCollins Publishers, New York.

Olthuis, J.H., Hart, H. \& Seerveld, C., 1970, Out of concern for the Church, Wedge, Toronto.

Schutte, A., 2004, 'Christianity and our world-view: European or African?', in C.W. du Toit (ed.), The integrity of the human person in an African context: perspectives from science and religion, pp. 45-47, UNISA, Pretoria.

Sue, D.W., Arredondo, P. \& McDavis, R.J., 1992, 'Multicultural counselling competencies and standards: A call to the profession', Journal of counselling and development 70(1), 477-486. https://doi.org/10.1002/j.1556-6676.1992.tb01642.x

Sue, D.W. \& Sue, D., 1999, Counselling the culturally different: Theory and practice, John Wiley \& Sons, New York.

Tutu, D.M., 1994, The rainbow people of God: The making of a peaceful revolution, Doubleday, New York.

Van der Walt, B.J., 2003, Understanding and rebuilding Africa, Institute for Contemporary Christianity in Africa, Potchefstroom.

Van der Walt, B.J., 2007, Transformed by the renewing of your mind, Institute for Contemporary Christianity in Africa, Potchefstroom.

Villa-Vicencio, C., 1994, 'Theology and culture in South Africa: beyond multiculturalism', Theology Today (50th anniversary edn.) 51(2), 115-126. https://doi. org/10.1177/004057369405100110

Wright, N.T., 2006, Evil and the justice of God, InterVarsity Press, Downers Grove.

Wolters, A.M., 1990, 'Christianity and the classics: a typology of attitudes', in W.E. Helleman (ed.), Christianity and the classics, pp. 189-203, University Press of America, Lanham. 